\title{
Forest Degradation Instigate Necessity of Launching Moratorium on Principle Loggings in Georgia
}

\author{
Tamaz Patarkalashvili* \\ Technical University of Georgia, Center Studying Productive Forces and Natural Resources of Georgia \\ *Corresponding author: Tamaz Patarkalashvili, Technical University of Georgia, Center Studying Productive Forces and Natural \\ Resources of Georgia
}

Keywords: Degradation; Moratorium; Reforestation; Loggings; Density; Extraction

\section{Editorial}

Mountain forests exploitation is problematic in all countries of the world. Among many other problems are logging and extraction of logged trees. These problems are sharpened according to the steepness of terrain. As steep are slopes, as more difficult is logging and tree extraction. Sometimes it is simply impossible physically and from ecological point of view, because on slopes of 40-50 degree of terrain the fallen trees moving downstairs by inertia break many trees and bushes on their way besides that they damage soil and forest floor.

Georgia is a mountainous country. The most part of forests (98\%) grow in mountains. Only $2 \%$ of forests grow in plains of Kolkhety flood lands and Alazani and Iori flood plains in east part of the country. From $98 \%$ of mountain forests $78 \%$ grow on steep and very steep slopes ( $36^{\circ}$ and more). The major part of productive forests of Georgia grows above 1000 meter of elevation, that complicates their exploitation. Due to these problems the principle loggings in Georgia was restricted from 1960 and submitting to their ecological importance. This restriction continued until the end of 1990. Forests grow unevenly in the country. Along with forest rich regions as Abkhazeti, Svanety, Racha, there are comparatively forest poor regions as Samtskhe-Javakhety, Kvemo Katrly, Kakhety [1].

Forests of Georgia have extremely important socio-ecological functions like: defense of soils from erosion, water resources protection and regulation, defense and mitigation from avalanches, mud-torrents, floods. They protect highlanders from strong cold winds in winter and snowstorms. They help slow penetration of melted water, regulate mineral water output in mountain spar resorts and so on [2,3]. Logging and extraction of trees are very problematic in mountain forests. From long-distance extraction of timber water is considered very efficient and economical but they are not always available, nor their use feasible. The load capacities of long-distance cable-ways are limited and they need skilled operating crews. Aerial methods of timber extraction was also used in last century with aerostats and helicopters. But as experiments showed aerostats have limited mobility in narrow gorges and are dangerous of accidental striking against trees. As to the helicopters they are too expensive and have limited loading capacity. They can't be used for group-selecting loggings because the felling area of the window for helicopter landing must be at least 50 meter in diameter that's prohibited in group-selecting logging method, as the windows must be maximum 20-25 meter in diameter. There is no doubts that roads are the best suited means for all purpose of long distance transportation in different terrain. Moreover, their use is open to all kind of vehicles. In short, roads are essential means to raise forest yields utilization to the maximum level of sustained production and to keep it there permanently [4].

According to the official statistics about $39-40 \%$ of Georgia's territory is covered by forests that's doubtful, as such percentage of country's territory was in late Soviet period when our forests was managed better. Forest inventory wasn't made after break-up of the Soviet Union. According to the unofficial information after 1990 illegally annually was logged and taken from the country about 5-6 million cubic meters of valuable forests, mostly beech-trees. The total amount of final loggings in last period was about 700800 cubic meter. Illegal loggings in early 2000 years were officially 43-63 thousand cubic meters, unofficially much more. From 2011 illegal loggings amount diminished a little to 5,3-7,0 thousand cubic meters [5]. In 1970-1990 the annual loggings were 432 thousand 
cubic meters by principal loggings and 500 thousand by sanitary and nursery loggings. If we compare these figures with analogical data of 2000, we'll see much difference. In 1974 the general scheme of development of forestry and utilization of forest resources of Georgian SSR was written. After thorough investigations of taxonomic indices of forests of Georgia was concluded that $55 \%$ of forests of the country were of 0.5 density and lower. High density forests ( 0.8 and more) where principal loggings can be conducted were only $6.1 \%$ [6]. So, it already indicated that our forests were degraded. After this alarming information annual principal loggings have been diminished to 432 thousand cubic meter that remained until the end of 1990s [7-9].

In 2008 our government gave on lease to Chinese, Italian and other business companies our most valuable forests in kakheti and Samegrelo-Zemo-Svanety on 25,30 and 49 years. All these objects are closed for specialists and journalists. All is wrapped in secrets. Nobody is allowed to enter in these territories, even local population who are not allowed to gather brushwood. Scientists are also not allowed to check what kind of exploitation takes place. As far as we know they mainly logging beech trees and export round wood instead of processing and export as materials. So, it can be concluded that brutal, extensive exploitation of our natural treasure is taking place. Our government likes to use the phrase, "sustainable management" but in fact they brutally exploit our natural resources to fill the country's budget this way instead of developing economy by modern technologies and innovations. We must remind who doesn't know that sustainable development is such development that meets the needs of present generations, without compromising the ability of future generations to meet their own needs in forestry. Sustainable forest management must be ecologically viable, economically feasible and socially desirable [10].

In conclusion we must underline that forest management in our country proceed unsustainably. There are many problems in restoration and reforestation, sowing and planting, promotion for natural regeneration, forest roads construction, illegal loggings, use of non-wood forest resources. Forests that was given on lease to foreign businessmen must be redeemed. The major part of our natural forests are degraded and need reconstruction and regeneration. Taking into account aforesaid we consider and believe that the only way to save our forests from complete destruction is launching moratorium on 50 years, like China and Indonesia who also launched moratorium on part of their forests [11-12]. Such moratorium protects our forests from complete destruction and allow them to recover.

\section{References}

1. Gigauri G (2000) Biodiversity of forests of Georgia. Pp. 160.

2. Patarkalashvili T (2016) Some problems of forest management of Georgia. Annals of agrarian science 14: 108-113.

3. Patarkalashvili T (1991) The Forest Resources of Georgia and the Problems of Their Rational Utilization. pp. 534-606.

4. Huber A (1995) Mountain Timber Extraction. Unasylva. 9(1): 12.

5. Patarkalashvili $\mathrm{T}$ (2015) Forest Resources In: Natural Resources of Georgia (I): 293-368.

6. (1980) Rules of Principle Loggings in Forests of Georgia. pp.32.

7. Targamadze K (1973) The forest fund of Georgia. pp.68.

8. Targamadze K, Chikhradze V (1976) Forest Resources of Georgian S.S.R. pp. 104.

9. (1975) General Scheme of Forestry Development and Forest Raw Materials in Georgian S.S.R. on 1976-1990, Working Paper.

10. Brandtland GH (1987) Our Common Future. Oxford University Press. New-York. USA, pp. 383.

11. Limin Dai, Shanlin Li, Lin Qi, Li Zhou, Dapao Yu, et al. (2018) Opportunities and challenges for the protection and ecological functions promotion of natural forests in China. Forest Ecology and Management 410: 187-192.

12. Busch J, Ferretti-Gallon K, Engelmann J, Wright M, Austin KG, et al. (2015) Reductions in emissions from deforestation from Indonesia's moratorium on oil palm, timber, and logging concessions. PNAS 112(5): 1328-1333.

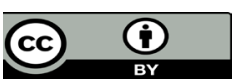

This work is licensed under Creative Commons Attribution 4.0 License

To Submit Your Article Click Here: Submit Article

DOI: $10.32474 /$ CIACR.2019.06.000242

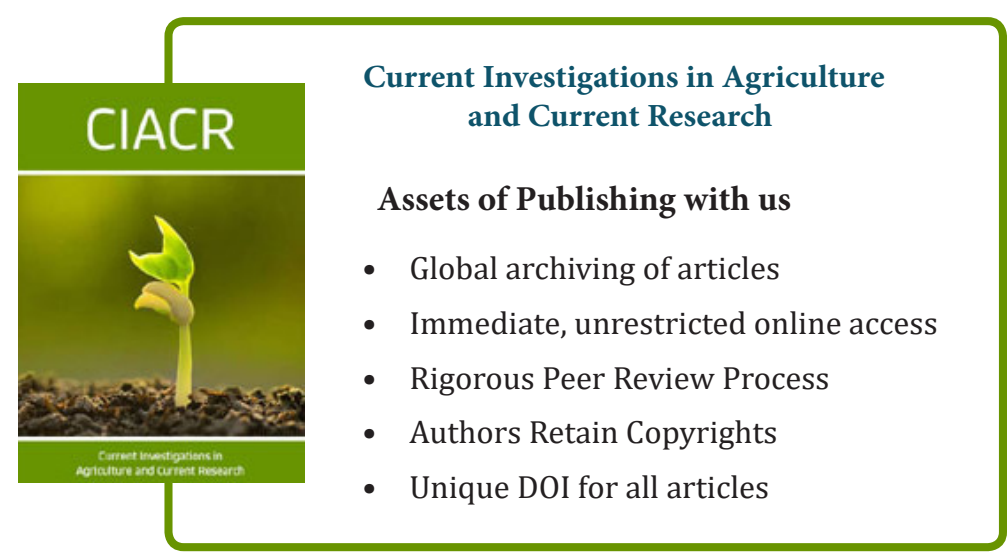

